\title{
PENGARUH KEPEMIMPINAN TRANSFORMASIONAL DAN MOTIVASI KERJA TERHADAP KINERJA KARYAWAN DI PT NINDOMARCO PRISMATAMA CABANG BOGOR 2
}

\author{
${ }^{1)}$ Yasnimar Ilyas, ${ }^{2)}$ Nia Novianti \\ ${ }^{1)}$ Dosen Tetap Program Studi Manajemen, STIE Dewantara \\ J1. Raya Pemda Bojong Depok Baru III Karadenan Cibinong Bogor, Jawa Barat 16913, Indonesia \\ Email: yasnimar.ilyas@dewantara.ac.id \\ ${ }^{2)}$ Alumni Program Studi Manajemen, STIE Dewantara \\ J1. Raya Pemda Bojong Depok Baru III Karadenan Cibinong Bogor, Jawa Barat 16913, Indonesia \\ Email: oppieninov@gmail.com
}

\begin{abstract}
The results showed 1) There was a positive and significant influence of motivation on the performance of employees of PT Unggul Karya Semesta Bogor with a tilapia regression coefficient of 0.409 and $t$ count $=11.204>t$ table 1.979 which proved the first hypothesis was accepted. 2) There is a positive and significant influence of transformational leadership on the performance of employees of PT Unggul Karya Semesta Bogor with a regression coefficient of 0.170 and $t$ count $=4.443>t$ table 1.979 which proves the second hypothesis is accepted. 3 ) There is a positive and significant influence of organizational culture on the performance of employees of PT Unggul Karya Semesta Bogor with a regression coefficient value of 0.403 and t count $=9461>t$ table 1.979 which proves the second hypothesis is accepted. 4) Simultaneous hypothesis test results known that the calculated $F$ value of 168,176> F table 2,445 has proves that together with motivation, transformational leadership and organizational culture have a significant effect on employee performance. 5) The coefficient of determination test results obtained adjusted $R^{2}$ value of 0.799 .
\end{abstract}

Keywords: Motivation, Transformasional Leadership, Organizational Culture.

\section{ABSTRAK}

Hasil penelitian menunjukkan 1) Terdapat pengaruh positif dan signifikan motivasi terhadap kinerja karyawan PT Unggul Karya Semesta Bogor dengan nila koefisien regresi sebesar 0,409 dan nilai $\mathrm{t}$ hitung $=11.204>\mathrm{t}$ tabel 1,979 yang membuktikan hipotesis pertama diterima. 2 ) Terdapat pengaruh positif dan signifikan kepemimpinan transformasional terhadap kinerja karyawan PT Unggul Karya Semesta Bogor dengan nilai koefisien regresi sebesar 0,170 dan nilai $\mathrm{t}$ hitung $=4.443>\mathrm{t}$ tabel 1,979 yang membuktikan hipotesis kedua diterima. 3) Terdapat pengaruh positif dan signifikan budaya organisasi terhadap kinerja karyawan PT Unggul Karya Semesta Bogor dengan nilai koefisien regresi sebesar 0,403 dan nilai $t$ hitung $=9.461>t$ table 1,979 yang membuktikan hipotesis kedua diterima. 4) Hasil uji hipotesis secara simultan diketahui nilai nilai F hitung $168.176>\mathrm{F}$ tabel 2.445 dengan hal ini membuktikan bahwa secara bersama-sama variable motivasi, kepemimpinan transformasional dan budaya organisasi mempunyai signifikan terhadap kinerja karyawan. 5) Hasil uji koefisien determinasi diperoleh nilai adjusted $R^{2}$ sebesar 0.799 .

Kata kunci : Motivasi, Kepemimpinan Transformasional, Kinerja Karyawan.

\begin{tabular}{lll}
\hline 1. PENDAHULUAN & faktor yang mempengaruhi kinerja \\
1.1 Latar Belakang & karyawan & selain kepemimpinan \\
Organisasi yang baik adalah organisasi & transformasional, yakni budaya organisasi. \\
yang berusaha menigkatkan kemampuan & Budaya organisasi adalah semua keyakinan, \\
sumber daya manusianya, karena hal & perasaan, perilaku dan simbol-simbol yang \\
tersebut merupakan faktor kunci untuk & mencirikan suatu organisasi. Hal ini \\
meningkatkan kinerja karyawan. Banyak & mengandung arti bahwa secara lebih
\end{tabular}


spesifik budaya organisasi dirumuskan sebagai pandangan, cita-cita, keyakinan, perasaan, prinsip-prinsip, harapan, sikap, norma dan nilai-nilai dari semua anggota organisasi.

Budaya organisasi menjadi hal yang sangat penting dan banyak dibicarakan akhir-akhir ini. Budaya organisasi adalah suatu kebiasaan yang telah berlangsung lama dan dipakai sebagai salah satu pendorong untuk meningkatkan kualitas sumber daya manusia. Sumber daya manusia selalu dituntut untuk meningkatkan kualitas dan keterampilannya dalam mengelola organisasi untuk mencapai tujuan yang telah ditetapkan. Berhasil tidaknya pencapaian tujuan yang dimaksud, budaya organisasi memegang peranan penting karena budaya organisasi merupakan suatu pandangan, cita-cita keyakinan, prinsip, harapan, sikap dan nilainilai dari semua anggota organisasi.

Kinerja karyawan PT Unggul Karya Semesta Bogor juga dapat diukur melalui penyelesaian tugasnya secara efektif dan efisien serta melakukan peran dan fungsinya, karena itu semua berhubungan linear dan berhubungan positif bagi keberhasilan suatu perusahaan. Terdapat faktor negatif yang dapat menurunkan kinerja karyawan, diantaranya adalah menurunnya keinginan karyawan untuk mencapai potensi kerja kurangnya ketepatan waktu dalam penyelesaian pekerjaan sehingga kurang menaati peraturan, pengaruh yang berasal dari lingkungannya, teman sekerja yang juga menurun semangatnya dan tidak adanya contoh yang harus dijadikan acuan dalam pencapaian prestasi kerja yang baik. Semua itu merupakan sebab menurunya kinerja karyawan dalam bekerja. Faktor-faktor yang dapat digunakan untuk meningkatkan kinerjadiantaranya adalah gaya kepemimpinan, motivasi dan disiplin kerja.

Berikut ini adalah data karyawan PT
Unggul Karya Semesta Bogor 4 bulan terakhir

Tabel 1. Data Absensi Karyawan Bulan Mei - Agustus 2018

\begin{tabular}{|c|c|c|c|c|c|c|}
\hline \multirow{2}{*}{ No } & \multirow{2}{*}{ Uraian } & \multicolumn{4}{|c|}{ Bulan } & \multirow{2}{*}{ Jumlah } \\
\hline & & Mei & Juni & Juli & Agustus & \\
\hline 1 & $\begin{array}{l}\text { Tidak Hadir Tanpa } \\
\text { Keterangan }\end{array}$ & 3 & 2 & 0 & 3 & 8 \\
\hline 2 & Keterlambatan & 4 & 5 & 3 & 2 & 14 \\
\hline 3 & Ijin Sakit & 7 & 6 & 4 & 3 & 20 \\
\hline 4 & \begin{tabular}{|l|} 
Ijin Keperluan \\
Keluarga \\
\end{tabular} & 2 & 1 & 0 & 4 & 7 \\
\hline 5 & $\begin{array}{l}\text { Meninggalkan Kantor } \\
\text { Tanpa Keterangan }\end{array}$ & 2 & 2 & 3 & 1 & 8 \\
\hline & Jumlah & 5 & 5 & 5 & 4 & 57 \\
\hline \multicolumn{2}{|r|}{ Jumlah Pegawai } & & & 185 & Persentase & $30,81 \%$ \\
\hline
\end{tabular}

Sumber: PT Unggul Karya Semesta

Berdasarkan data di atas diketahui selama 4 bulan terakhir yaitu periode Bulan Mei - Agustus 2018, sebesar 30, 81\% absensi karyawan menunjukkan tingkat yang kurang maksimal. Motivasi adalah dorongan, upaya dan keinginan yang ada di dalam diri manusia yang mengaktifkan, memberi daya serta mengarahkan perilaku untuk melaksanakan tugas-tugas dengan baik dalam lingkup pekerjaannya.

\subsection{Ruang Lingkup Permasalahan}

Untuk mempermudah penulisan laporan penelitian ini agar lebih terarah dan berjalan dengan baik, maka perlu kiranya dibuat suatu batasan masalah.Maka ruang lingkup peneliti dibatasi hanya ditunjukan pada karyawan PT Unggul Karya Semesta Bogor serta faktor-faktor yang berkaitan dengan variabel penelitian serta pengaruhnya terhadap kinerja karyawan PT Unggul Karya Semesta Bogor.

\subsection{Perumusan Masalah}

Berdasarkan latar belakang dan ruang lingkup masalah sebagaimana disebutkan sebelumnya, maka penelitian ini dapat dirumuskan permasalahan sebagai berikut :

1. Bagaimana pengaruh motivasi terhadap kinerja karyawan PT Unggul Karya Semesta Bogor? 
2. Bagaimana pengaruh kepemimpinan transformasional terhadap kinerja karyawan PT Unggul Karya Semesta Bogor?

3. Bagaimana pengaruh budaya organisasi terhadap kinerja karyawan PT Unggul Karya Semesta Bogor?

4. Bagaimana pengaruh motivasi, kepemimpinan transformasional dan budaya organisasi secara simultan terhadap kinerja karyawan PT Unggul Karya Semesta Bogor?

5. Bagaimana variabel motivasi, kepemimpinan transformasional dan budaya organisasi secara simultan dapat menjelaskan kinerja karyawan PT Unggul Karya Semesta Bogor ?

6. Variabel manakah yang dominan berpengaruh terhadap kinerja karyawan PT Unggul Karya Semesta Bogor?

\subsection{Tujuan Penelitian}

Setiap penelitian pasti memiliki tujuan, tujuan yang ingin dicapai penelti setelah melakukan penelitian berdasarkan permasalahan adalah :

1. Untuk mengetahui pengaruh motivasi terhadap kinerja karyawan PT Unggul Karya Semesta Bogor.

2. Untuk mengetahui pengaruh kepemimpinan transformasional terhadap kinerja karyawan PT Unggul Karya Semesta Bogor.

3. Untuk mengetahui pengaruh budaya organisasi terhadap kinerja karyawan PT Unggul Karya Semesta Bogor.

4. Untuk mengetahui pengaruh motivasi, kepemimpinan transformasional dan budaya organisasi secara simultan terhadap kinerja karyawan PT Unggul Karya Semesta Bogor.

5. Untuk menhetahui variabel motivasi, kepemimpinan transformasional dan budaya organisasi secara simultan dapat menjelaskan kinerja karyawan PT Unggul Karya Semesta Bogor.
7. Untuk mengetahui variabel yang dominan berpengaruh terhadap kinerja karyawan PT Unggul Karya Semesta Bogor.

\section{TINJAUAN PUSTAKA}

\subsection{Landasan Teori}

\subsubsection{Pengertian Kinerja}

Hasibuan (20014:6) mengemukakan bahwa kinerja adalah suatu hasil kerja yang di capai seseorang dalam melaksanakan tugas-tugas yang dibebankan kepadanya yang didasarkan atas kecakapan, pengalaman dan kesungguhan serta waktu.

Dengan kata lain bahwa kinerja adalah hasil kerja yang dicapai seseorang dalam melaksanakan tugas yang diberikan kepadanya sesuai dengan kreteria yang ditetapkan. Selanjutnya As'ad (2003:6) mengumukakan bahwa kinerja seseorang merupakan ukuran sejauh mana keberhasilan seseorang dalam melakukan tugas pekerjaannya.

\subsubsection{Faktor-faktor yang Mempengaruhi Kinerja}

Kinerja seorang karyawan denga karywan yang lainnya dalam perusahaan tentunya berbeda-beda, tergantung dari fakor-faktor yang mempengaruhinya. Rasa puasa yang di dapatkan karyawa disaat mereka bekerja, dapat membuat mereka bekerja secara maksimal dan menunjukkan hasil terbaik.Hal tersebut merupakan wujud timbal balik yang diberikan karyawan kepada perusahaan.Selain memberikan kepuasan kepada karyawan, kegairahan kerja dengan memberikan motivasi perlu diciptakan agar karyawan bekerja dengan efektif.

Menurut Tiffin dan Mc. Cormick (dalam As'ad, 2003:49) ada dua variabel yang mempengaruhi kinerja, yaitu :

1. Variabel Individual yaitu meliputi sikap, karakteristik, kepribadian, sifatsifat fisik, minat dan motivasi, pengalaman, umur, jenis kelamin, 
pendidikan serta faktor individual lainnya.

2. Variabel Situasional yang terdiri dari :

a. Faktor fisik pekerjaan meliputi metode kerja, kondisi dan desin perlengkapan kerja, penata ruang lingkungan fisik (penyinaran, temperatur dan ventilasi)

b. Faktor sosial dan organisasi meliputi peraturan organisasi, jenis latihan, pengawasan, sistem upah dan lingkungan sosial.

Indikator kinerja merupakan aspekaspek yang menjadi ukuran dalam menilai kinerja. Adapun mengenai indikator yang menjadi ukuran kinerja menurut Mathis \& Jakson (2006:378) adalah sebagai berikut :

a. Kuantitas

Merupakan jumlah yang dihasilkan, dinyatakan dalam istilah seperti jumlah unit, jumlah siklus aktivitas yang diselesaikan karyawan, dan jumlah aktivitas yang dihasilkan.

b. Kualitas

Kualitas kerja diukur dari persepsi karyawan terhadap kualitas pekerjaan yang dihasilkan serta kesempurnaan tugas terhadap keterampilan dan kemampuan karyawan.

c. Ketepatan Waktu

Ketepatan waktu diukur dari persepsi karyawan terhadap suatu aktivitas yang diselesaikan di awal waktu sampai menjadi output.

d. Kehadiran

Kehadiran karyawan di perusahaan baik dalam masuk kerja, pulang kerja, izin maupun tanpa keterangan yang seluruhnya mempengaruhi kinerja karyawan itu.

e. Kemampuan Bekerja Sama

Kemampuan bekerja sama adalah kemampuan seseorang tenaga kerja untuk bekerja sama dengan orang lain dalam menyelesaikan tugas dan pekerjaan yang telah ditetapkan sehingga mencapai daya guna dan hasil yang sebesar-besarnya.

\subsubsection{Pengertian Motivasi}

Menurut Robbins (2015: 112) motivasi mengacu pada proses dimana usaha seseorang yang bersemangat, diarahkan, dan berkelanjutan menuju pencapaian tujuan. Definisi ini memiliki tiga elemen kunci, energi, arah, dan ketekunan. elemen energi ukuran intensitas, drive dan kekuatan orang termotivasi menempatkan sebagainya upaya dan bekerja keras.Namun, kualitas usaha harus dipertimbangkan juga intensitasnya tingkat usaha tidak selalu mengarah pada kinerja pekerjaan yang menguntungkan kecuali usaha disalurkan dalam arah yang menguntungkan organisasi. Upaya yang diarahkan, dan konsisten dengan, tujuan organisasi adalah jenis usaha yang kita inginkan dari karyawan. Akhirnya, motivasi termasuk dimensi ketekunan yang diinginkan karyawan untuk bertahan dalam menempatkan sebagainya upaya untuk mencapai tujuan tersebut.

Mathis dan Jackson (2006:164) mengemukakan bahwa teori motivasi Hygiene Herzberg mengasumsikan bahwa sekelompok factor, motivator, menyebabkan tingkat kepuasan dan motivasi kerja yang tinggi. Akan tetapi faktor-faktor Hygiene dapat menimbulkan ketidakpuasan kerja.

Hierarki kebutuhan Maslow memiliki 5 tingkatan, untuk lebh jelasnya berikut ini gambar Hierarki kebutuhan Maslow. 


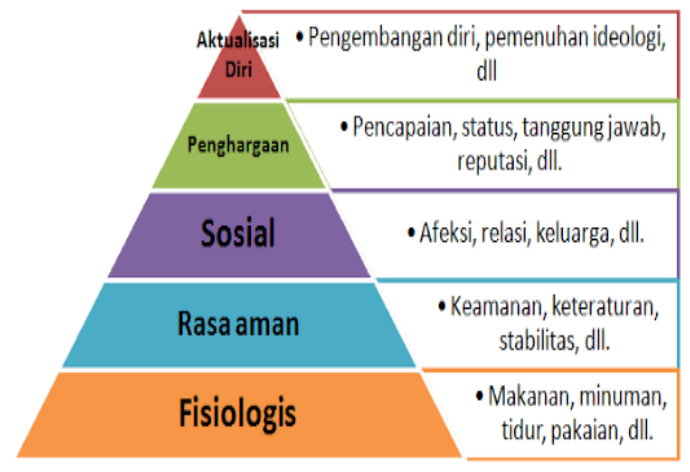

Gambar 1. Hierarki

Kebutuhan

Maslow dalam Wibowo (2010:379)

\subsubsection{Pengertian \\ Transformasional}

\section{Kepemimpinan}

Menurut Veithzal Rivai (2011 : 163) kepemimpinan juga dikatakan sebagai proses mengarahkan dan mempengaruhi aktivitas-aktivitas yang ada hubungannya dengan pekerjaan para anggota kelompok. Dari kualitas kepemimpinan dan pemimpin tersebut yang menentukan keberhasilan lembaga atau organisasi tersebut terus banyak memunculkan teori - teori kepemimpinan.

Menurut Yukl, (2010:313), kepemimpinan transformasional adalah suatu keadaan dimana para pengikut dari seorang pemimpin transformasional merasa adanya kepercayaan, kekaguman, kesetiaan, dan hormat terhadap pemimpin tersebut, dan mereka termotivasi untuk melakukan lebih dari pada yang awalnya diharapkan mereka.

Menurut Robbins dan Judge $(2015 ; 90)$, pemimpin transformasional adalah pemimpin yang menginspirasi para pengikutnya untuk menyampingkan kepentingan pribadi mereka demi kebaikan organisasi dan mampu memiliki pengaruh yang luar biasa pada diri para pengikutnya.

Ada empat dimensi kepemimpinan transformasional, yaitu:

1. Karisma, dengan memberikan rasa visi dan misi serta menanamkan rasa bangga dan hormat serta rasa percaya diri kepada pengikutnya.

2. Inspirasi, harapan tinggi-harapan yang dikomunikasikan dengan menggunakan simbol-simbol untuk upaya fokus bertujuan dan menjelaskan tujuan penting dengan mudah.

3. Stimulasi Intelektual, dengan cara meningkatkan kecerdasan, rasionalitas dan menyelesaikan masalah dengan hati-hati.

4. Perhatian Individu, perhatian diberikan secara individual untuk memperlakukan karyawan sendiri dalam memberikan pelatihan dan saran.

\subsubsection{Pengertian Budaya Organisasi}

Ndraha (2003:4) dalam Brahmasari (2004:12) mengemukakan bahwa budaya perusahaan (corporate culture) merupakan aplikasi dari budaya organisasi (organizational culture) terhadap badan usaha atau perusahaan. Kedua istilah ini sering dipergunakan untuk maksud yang sama secara bergantian.

Sementara itu Robbins (2011:20-21) menjelaskan mengenai 3 (tiga) kekuatan untuk mempertahankan suatu budaya organisasi sebagai berikut: (1) Praktik seleksi, proses seleksi bertujuan mengidentifikasi dan mempekerjakan individu-individu yang mempunyai pengetahuan, ketrampilan, dan kemampuan untuk melakukan pekerjaan dengan sukses dalam organisasi. (2) Manajemen puncak, tindakan manajemen puncak mempunyai dampak besar pada budaya organisasi. Ucapan dan perilaku mereka dalam melaksanakan norma-norma sangat berpengaruh terhadap anggota organisasi. (3) Sosialisasi, sosialisasi dimaksudkan agar para karyawan baru dapat menyesuaikan diri dengan budaya organisasi. Proses sosialisasi ini meliputi tiga tahap yaitu tahap kedatangan, tahap pertemuan dan tahap metromofis. Terdapat tujuh karakteristik utama yang secara 
keseluruhan (Siagian, 2009: 110) yaitu sebagai berikut :

1. Innovation and Risk Talking (Inovasi dan Pengambilan Resiko) adalah suatu tingkatan dimana pekerja didorong untuk menjadi inovatif dan mengambil resiko

2. Attention to Detail (Perhatian pada Hal-hal Detail) dimana pekerja diharakan menunjukkan ketepatan, anlisis, dan perhatian pada hal detail.

3. Outcome Oritentation (Orientasi pada Manfaat) yang mana manajemen memfokuskan pada hasil atau manfaat dari yang tidak hanya sekedar teknik dan proses untuk mendapatkan manfaat tersebut.

4. People Orientation (Orientasi pada Orang) dimana keputusan manajemen mempertimbangkan pengaruh manfaatnya pada orang dalam organisasi.

5. Team Orientation (Orientasi pada Tim) dimana aktivitas kerja di organisasi berdasar tim daripada individual.

6. Aggresiveness (Agresivitas) dimana orang cenderung lebih agresif dan kompetitif daripada easy going.

7. Stability (Stabilitas) yang mana aktivitas organisasional tersebut menekankan pada menjaga status sebagai lawan dari pada perkembangan.

\subsection{Hipotesis Penelitian}

Hipotesis merupakan jawaban sementara terhadap rumusan masalah penelitian, dimana rumusan masalah penelitian telah dinyatakan dalam bentuk kalimat pernyataan (Sugiono, 2016:64). Berikut ini adalah hipotesis dalam penelitian ini :

Ho: Tidak terdapat pengaruh motivasi, kepemimpinan transformasional dan budaya organisasi secara parsial maupun simultan terhadap kinerja karyawan PT Unggul Karya Semesta Bogor.

H1 : Terdapat pengaruh motivasi terhadap kinerja karyawan PT Unggul Karya Semesta Bogor.

$\mathrm{H} 2$ : Terdapat pengaruh kepemimpinan transformasional terhadap kinerja karyawan PT Unggul Karya Semesta Bogor.

H3 : Terdapat pengaruh budaya organisasi terhadap kinerja karyawan PT Unggul Karya Semesta Bogor.

H4 : Terdapat pengaruh motivasi, kepemimpinan transformasional dan budaya organisasi secara parsial maupun simultan terhadap kinerja karyawan PT Unggul Karya Semesta Bogor.

\section{METODE PENELITIAN}

\subsection{Jenis Penelitian}

Jenis penelitian ini adalah kuantitatif kausalitas yaitu salah satu teknik statistik yang digunakan untuk mencari hubungan antara dua variabel atau lebih yang sifatnya kuantitatif.

\subsection{Lokasi dan Waktu Penelitian}

Lokasi penelitian adalah tempat yang di jadikan sebagai objek pengumpulan data. Maka lokasi yang di pilih dalam penelitian ini adalah Jl Raya Wanaherang Gunung Putri Bogor, Bogor, Jawa Barat.Penelitian dilakukan selama 5 (lima) bulan sejak Juli 2018 sampai Nopember 2018.

\subsection{Populasi dan Sampel}

Populasi dalam penelitian ini adalah seluruhan karyawan yang berstatus karyawan tetap bagian produksi pada PT Unggul Karya Semesta yang berjumlah berjumlah 185 pegawai. Teknik pengambilan sampel dalam penelitian ini adalah teknik purposive sampling yaitu teknik sampling yang memberi peluang/kesempatan sama bagi setiap unsur 
atau anggota populasi untuk dipilih menjadi sampel. Peneliti memilih teknik pengambilan sampel jenuh atau lebih dikenal sebagai sensus. Sampel jenuh merupakan teknik penentuan sampel bila semua anggota populasi digunakan sebagai sampel (Sugiono, 2016:79). Jumlah sampel dalam penelitian ini dihitung dengan menggunakan rumus Slovin berikut :

$$
\mathrm{n}=\frac{N}{1+N e^{3}}
$$

Keterangan :

$$
\begin{aligned}
& \mathrm{n}=\text { jumlah sampel yang dibutuhkan } \\
& \mathrm{N}=\text { populasi dari keseluruhan sampel } \\
& \mathrm{e}=\text { margin of error }(5 \%) \\
& \mathrm{n}=\frac{185}{1+\left(185 \times 0,05^{2}\right)} \\
& \mathrm{n}=\frac{185}{1.462} \\
& \mathrm{n}=126.49 \text { dibulatkan menjadi } 127
\end{aligned}
$$
sampel

\subsection{Teknik Analisis Data}

Setelah memperoleh data-data angket, maka selanjutnya dilakukan proses pengolahan data yang disajikan dalam bentuk tabel. Untuk pengolahan data dari hasil angket, maka penulis menggunakan metode skala likert nilai dalam skala likert variabel yang akan diukur dijabarkan menjadi indikator variabel dan dijadikan sebagai titik tolak untuk menyusun itemitem instrument yang menggunakan skala likert mempunyai gradasi dari sangat positif sampai dengan sangat negatif.

1. Analisis Regresi Linier Berganda

2. Uji Koefisien Korelasi

3. Pengujian Hipotesis

4. Koefisien Determinasi $\left(\mathrm{R}^{2}\right)$

\begin{tabular}{|c|c|c|c|c|c|c|}
\hline \multicolumn{7}{|c|}{ Coefficients $^{2}$} \\
\hline \multirow{2}{*}{\multicolumn{2}{|c|}{ Model }} & \multicolumn{2}{|c|}{$\begin{array}{l}\text { Unstandardized } \\
\text { Coefficients }\end{array}$} & \multirow{2}{*}{$\begin{array}{c}\begin{array}{c}\text { Standardized } \\
\text { Coefficients }\end{array} \\
\text { Beta }\end{array}$} & \multirow{2}{*}{ t } & \multirow{2}{*}{ Sig. } \\
\hline & & B & $\begin{array}{l}\text { Std. } \\
\text { Error }\end{array}$ & & & \\
\hline 1 & (Constant) & 3,08 & 3,662 & & 0,841 &, 402 \\
\hline & Motivasi & ,409 &, 037 &, 533 & 11,204 & ,000 \\
\hline & Kepemimpinan & 170 & .038 & 204 & 4443 & 000 \\
\hline & Transformasional & & & & & \\
\hline & Budaya Organisasi &, 403 &, 043 & ,409 & 9,461 & ,000 \\
\hline
\end{tabular}

4. HASIL DAN PEMBAHASAN

4.1 Uji Regresi Linear Berganda

Berikut ini hasil analisis regresi linear berganda dalam penelitian ini :

\section{Tabel 2. Hasil Uji Regresi Linear Berganda}

Sumber : data primer yang diolah, 2019

Berdasarkan hasil uji regresi linear berganda seperti tampak pada tabel di atas diperoleh persamaan regresi yaitu: $\mathrm{Y}=$ $3.080+0,409 \mathrm{X}_{1}+0,170 \mathrm{X}_{2}+0.403 \mathrm{X}_{3}$. Nilai koefisien regresi dari variabel di atas menunjukkan besarnya pengaruh variabel bebas terhadap variabel terikat. Semakin besar nilai pada koefisien variabel bebas (X), maka semakin besar pula pengaruhnya terhadap variabel terikat $(\mathrm{Y})$.

Dari hasil uji regresi di atas juga diketahui bahwa variabel yang paling dominan mempengaruhi kinerja karyawan adalah variabel motivasi hal ini terlihat dari nilai koefisien regresi variabel motivasi sebesar 0,409.

\subsection{Uji Korelasi}

Uji koelasi dalam penelitian ini dilakukan untuk mengetahui besarnya nilai hubungan atau koefisien korelasi antara variabel bebas (X) dengan variabel terikat (Y). Berikut ini hasil uji korelasi dalam penelitian ini. 
Tabel 3. Hasil Uji Korelasi

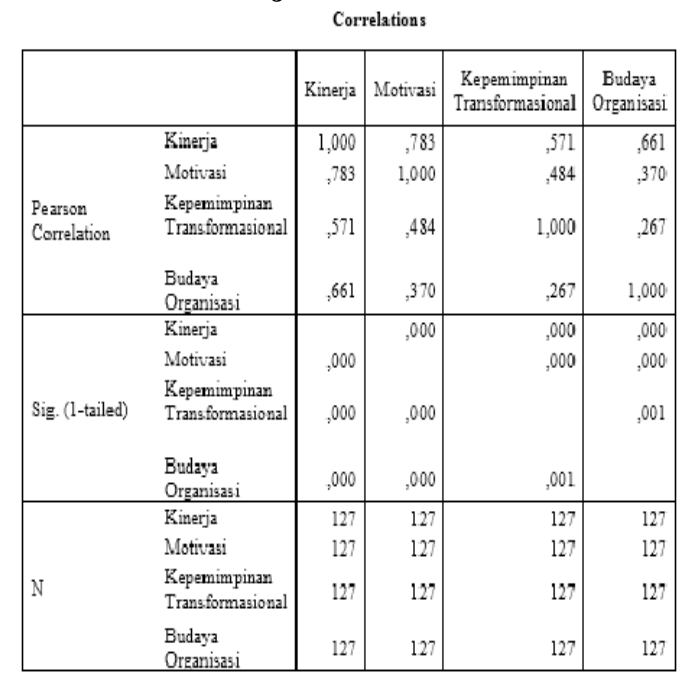

Sumber : data primer yang diolah, 2019

Berdasarkan hasil uji korelasi diatas diperoleh kesimpulan sebagai berikut:

1. Nilai korelasi atau $r$ untuk variabel motiavasi sebesar 0,783 yang artinya kuat. Hal ini menunjukkan bahwa tingkat hubungan motivasi dengan kinerja berada pada tingkat yang kuat.

2. Nilai korelasi atau $r$ untuk variabel kepemimpinan transformasional sebesar 0,571 yang artinya sedang. Hal ini menunjukkan bahwa tingkat hubungan keemimpinan transformasional dengan kinerja berada pada tingkat yang sedang.

3. Nilai korelasi atau $\mathrm{r}$ untuk variabel budaya organisasi sebesar 0,661 yang artinya sedang. Hal ini menunjukkan bahwa tingkat hubungan budaya organisasi dengan kinerja berada pada tingkat yang sedang.

\subsection{Uji Hipotesis \\ 4.3.1 Uji Secara Parsial (t)}

Tabel 4. Hasil Uji Hipotesis Secara Parsial

\begin{tabular}{|l|c|c|c|c|c|}
\hline \multicolumn{1}{|c|}{ Variabel } & $\begin{array}{c}\text { nilai t } \\
\text { hitung }\end{array}$ & $\begin{array}{c}\text { nilai t } \\
\text { takel }\end{array}$ & Sig, & $\alpha$ & Keputusan \\
\hline Motivasi (X1) & 11204 & 1,979 & 0,000 & 0,05 & $\begin{array}{l}\text { Ho ditolak, } \\
\text { Ha diterima }\end{array}$ \\
\hline $\begin{array}{l}\text { Kepemimpinan } \\
\text { Transformasional } \\
\text { (X2) }\end{array}$ & 4443 & 1,979 & 0,000 & 0,05 & $\begin{array}{l}\text { Ho ditolak, } \\
\text { Ha diterima }\end{array}$ \\
\hline $\begin{array}{l}\text { Budaya } \\
\text { Organisasi (X3) }\end{array}$ & 9461 & 1,979 & 0,000 & 0,05 & $\begin{array}{l}\text { Ho ditolak, } \\
\text { Ha diterima }\end{array}$ \\
\hline
\end{tabular}

Sumber : data primer yang diolah, 2019

Berdasarkan hasil uji hipotesis seacara parsial seperti pada tabel di atas maka dapat dijelaskan sebagai berikut:

1. Variabel Motivasi

Hasil pengujian menunjukkan koefisien regresi variabel motivasi bertanda positif sebesar 0,409 dan nilai $\mathrm{t}$ hitung $=11.204>\mathrm{t}$ table 1,979 dengan nilai signifikansi sebesar $0.000<0,05$. Nilai signifikansi yang lebih kecil dari 0,05 menunjukkan bahwa pada taraf signifikansi 5\% maka hipotesis yang menyatakan bahwa variabel motivasi memiliki pengaruh positif dan signifikan terhadap kinerja karyawan dapat diterima.

2. Variabel Kepemimpinan Transformasional Hasil pengujian menunjukkan koefisien regresi variabel kepemimpinan transformasional bertanda positif sebesar 0,170 dan nilai $\mathrm{t}$ hitung $=$ 4.443> $\mathrm{t}$ table 1,979 dengan nilai signifikansi sebesar $0.000<0,05$. Nilai signifikansi yang lebih kecil dari 0,05 menunjukkan bahwa pada taraf signifikansi 5\% maka hipotesis yang menyatakan bahwa variabel kepemimpinan transformasional memiliki pengaruh positif dan signifikan terhadap kinerja karyawan dapat diterima. 
3. Variabel Budaya Organisasi

Hasil pengujian menunjukkan koefisien regresi variabel budaya organisasi bertanda positif sebesar 0,403 dan nilai $\mathrm{t}$ hitung $=9.461>\mathrm{t}$ table 1.979 dengan nilai signifikansi sebesar $0,000<0.05$ menunjukkan bahwa pada taraf signifikansi $5 \%$ hipotesis yang menyatakan bahwa budaya organisasi memiliki pengaruh positif dan signifikan terhadap terhadap kinerja karyawandapat diterima.

\subsubsection{Uji Secara Silmutan (F)}

Tabel 5. Hasil Uji Hipotesis Secara Simultan

\begin{tabular}{|c|c|c|c|c|c|}
\hline \multicolumn{6}{|c|}{$\mathrm{ANOVA}^{2}$} \\
\hline Model & $\begin{array}{l}\text { Sum of } \\
\text { Squares }\end{array}$ & df & $\begin{array}{l}\text { Mean } \\
\text { Square }\end{array}$ & $\mathrm{F}$ & Sig. \\
\hline 1 Regression & 7453,090 & 3 & 2484,363 & 168,176 &, $000^{\circ}$ \\
\hline Residual & 1817,005 & 123 & 14,772 & & \\
\hline Total & 9270,094 & 126 & & & \\
\hline
\end{tabular}

Sumber : data primer yang diolah, 2019

Berdasarkan hasil uji hipotesis secara simultan seperti tampak pada table ANOVA di atas, diketahui nilai $\mathrm{F}$ hitung = 168.176 dengan signifikansi sebesar 0,000. Dan diketahui nilai $\mathrm{F}$ table untuk sampel berjumlah 127 adalah $=2.445$. Berdasarkan ketentuan hipotesis bahwa Ho ditolak dan Ha diterima jika $F$ hitung $>F$ tabel maka dengan demikian dalam penelitian ini karena nilai $\mathrm{F}$ hitung 168.176> F tabel 2.445 maka hipotesis yang menyatakan bahwa secara bersama-sama variabel motivasi, kepemimpinan transformasional dan budaya organisasi mempunyai pengaruh positif dan signifikan terhadap kinerja karyawan dapat di terima.

\subsection{Uji Koefisien Determinasi $\left(\mathbf{R}^{\mathbf{2}}\right)$}

Uji Koefisien determinasi dilakukan untuk mengetahui besarnya pengaruh bebas $(\mathrm{X})$ terhadap variabel terikat $(\mathrm{Y})$.
Berikut ini adalah hasil uji koefisien determinasi dalam penelitian ini.

\section{Tabel 6. Hasil Uji Koefisien} Determinasi

\begin{tabular}{|r|r|r|r|c|}
\hline Model & $\mathrm{R}$ & $\begin{array}{c}\mathrm{R} \\
\text { Square }\end{array}$ & $\begin{array}{c}\text { Adjusted } \\
\mathrm{R} \\
\text { Square }\end{array}$ & $\begin{array}{c}\text { Std. } \\
\text { Error of } \\
\text { the } \\
\text { Estimate }\end{array}$ \\
\hline 1 &, $897^{\mathrm{a}}$ & 0,804 & 0,799 & 3,84349 \\
\hline
\end{tabular}

Sumber : data primer yang diolah, 2019

Berdasarkan hasil uji koefisien determinasi di atas dapat diketahui bahwa nilai koefisien determinasi (adjusted $R^{2}$ ) yang di peroleh sebesar 0.799 hal ini berarti 79.9\% kinerja karyawan dipengaruhi oleh motivasi, kepemimpinan transformasional dan budaya organisasi sedangkan sisanya yaitu $20.1 \%$ kinerja karyawan di pengaruhi oleh variabel-variabel lainnya yang dalam penelitian ini tidak diteliti.

\section{KESIMPULAN DAN SARAN}

\subsection{Kesimpulan}

Berdasarkan uraian hasil penelitian dan pembahasan pada bab sebelumnya maka dalam penelitian ini kesimpulannya adalah sebagai berikut:

1. Terdapat pengaruh signifikan motivasi terhadap kinerja karyawan PT Unggul Karya Semesta Bogor dengan nilai koefisien regresi sebesar 0,409dan nilai $\mathrm{t}$ hitung $=11.204>\mathrm{t}$ tabel 1,979 yang membuktikan hipotesis pertama diterima.

2. Terdapat pengaruh signifikan kepemimpinan transformasional terhadap kinerja karyawan PT Unggul Karya Semesta Bogor dengan nilai koefisien regresi sebesar 0,170dan nilai $\mathrm{t}$ hitung $=4.443>\mathrm{t}$ tabel 1,979 yang membuktikan hipotesis kedua diterima.

3. Terdapat pengaruh signifikan budaya organisasi terhadap kinerja karyawan PT Unggul Karya Semesta Bogor dengan nilai koefisien regresi sebesar 0,403 dan nilai $\mathrm{t}$ hitung $=9.461>\mathrm{t}$ tabel 
1,979 yang membuktikan hipotesis kedua diterima.

4. Hasil uji hipotesis secara simultan diketahui nilai nilai $\mathrm{F}$ hitung 168.176> F tabel 2.445 dengan signifikansi 5\% ha ini membuktikan bahwa secara bersama-sama variabel motivasi, kepemimpinan transformasional dan budaya organisasi mempunyai signifikan terhadap kinerja karyawan.

5. Hasil uji koefisien determinasi diperoleh nilai adjusted $R^{2}$ sebesar 0.799 hal ini berarti $79.9 \%$ kinerja karyawan dipengaruhi oleh motivasi, kepemimpinan transformasional dan budaya organisasi sedangkan sisanya yaitu $20.1 \%$ kinerja karyawan di pengaruhi oleh variabel-variabel lainnya yang dalam penelitian ini tidak diteliti.

6. Variabel yang paling dominan mempengaruhi kinerja karyawan adalah variabel motivasi hal ini terlihat dari nilai koefisien regresi variabel motivasi sebesar 0,409

\subsection{Saran}

Berdasarkan hasil kesimpulan yang diuraikan di atas maka saran-saran yang dapat penulis sampaikan dalam penelitian ini adalah:

1. Motivasi kerja yang terbukti memiliki pengaruh dominan terhadap kinerja karyawan PT Unggul Karya Semesta Bogor, maka sebaiknya pihak manajemen terus menjaga dan mempertahankan motivasi kerja karyawan yang selama ini dinilai baik.

2. Kepemimpinan transformasional yang dalam penelitian ini terbukti memiliki pengaruh yang lebih kecil dibanding dengan motivasi dan budaya organisasi terhadap kinerja karyawan, maka sebaiknya, pihak pimpinan lebih meningkatkan lagi komunikasi dengan karyawan agar nantinya terjalin ubungan yang harmonis antara atasan dan karyawansehingga diharapkan akan mmberikan dampak terhadap kinerja karyawan yang lebih baik

3. Untuk penelitian selanjutnya penulis menyarankan agar dicari asumsiasumsi lain selain motivasi, kepemimpinan transformaisonal dan budaya organisasi yang sekiranya dapat mempengaruhi kinerja pegawai, misalnya, kepuasan kerja, kompensasi, disiplin dan lain sebagainya.

\section{DAFTAR PUSTAKA}

As' ad, Moh. 2003. Seri Ilmu Sumber Daya Manusia, Psikologi Industri. Edisi keempat. Yogyakarta: Liberty.

Bass, Bernard M, dan Riggio, Ronald E, 2005, Transformasional Leadership. New Jersey : Lawrance Erlbawn Associates, Publishers.

Brahmasari Ida Ayu, 2004. Pengaruh Variabel Budaya Perusahaan terhadap Komitmen Karyawan dan Kinerja Perusahaan Kelompok penerbitan Pers Jawa pos,Disertai Universitas Airlangga Surabaya.

David McClelland dan A.H. Maslow, Frederick Herzberg, dan. 2005. Job Satisfaction Theory.

Dharma, Agus 2001.Manajemen Supervisi. Jakarta: Raja Grafindo Persada.

Danim, Sudarwan. 2004. Motivasi Kepemimpinan \& Efektivitas Kelompok. Jakarta: PT Rineka Cipta

Ghozali, Imam. 2009. Aplikasi Analisis Multivariate dengan program SPSS,Semarang : Badan Penerbit Universitas Diponegoro

Gibson, 2003 . Organisasi Perilaku-struktur -proses, Terjemahan, Edisi V. Jakarta: Penerbit Erlangga

Handayaningrat, Soewarno. 2006, Pengantar Studi Ilmu Administrasi dan Manajemen, Jakarta:Gunung Agung 
Handoko, T. Hani. 2012. Manajemen Personalia dan Sumber Daya Manusia. Yogyakarta: BPFE

Hasibuan, Malayu S.P. 2014. Manajemen Sumber Daya Manusia, Edisi Revisi, Jakarta: PT. Bumi Aksara

Ilyas, Yasnimar. 2017. "Commitment To Organizations Viewed From Transformational Leadership And Work Satisfaction (Study on Teachers of Private Junior High Schools in Bogor Regency).

Kuncoro, Mudrajad.2007. Metode Kuantitatif: Teori dan Aplikasi Untuk Bisnis dan Ekonomi. Yogyakarta: UPP STIM YKPN.

Mangkunegara, A.A. Anwar Prabu 2009 Manajemen Sumber Daya Manusia, Cetakan kelima, Penerbit PT. Remaja Rosdakarya. Bandung.

Marihot, Tua Efendi Hariandja, (2009) : Manajemen Sumber Daya Manusia, Pengadaan, Pengembangan, Pengkompensasian, Peningkatan Produktivitas Pegawai. Jakarta : Grafindo

M. Manullang. 2002. Dasar-dasar Manajemen. Cetakan 16.Yogyakarta : Gadjah Mada University Pres

Mathis, R.L. \& J.H. Jackson. 2006. Human Resource Management: Manajemen Sumber Daya Manusia. Terjemahan Dian Angelia. Jakarta: Salemba Empat.

Nur Indriantoro dan Bambang Supomo. 2002. Metodologi Penelitian Bisnis. Yogyakarta : BPFE.

Perna Pratini dan I Wayan Mudiartha Utama (Pengaruh Kepemimpinan Transformasional Dan BudayaOrganisasi Terhadap Motivasi Dan Kinerja Karyawan) E-Jurnal Manajemen Unud, Vol. 5, No.7, 2016: 4337-4366 ISSN : 2302-8912

Rivai, Veithzal, 2005. Manajemen Sumber Daya Manusia untuk Perusahaan, dari.Teori ke Praktik, Jakarta: PT. Raja Grafindo Persada.
Rivai, Veithzal, 2011. Manajemen Sumber Daya Manusia untuk Perusahaan, dari.Teori ke Praktik, Jakarta: PT. Raja Grafindo Persada.

Robbins, Stephen P. dan Timothy A. Judge. 2011.Perilaku Organisasi.Edisi ke12,Jakarta:Salemba Empat.

Rosidah, 2003, Manajemen Sumber Daya Manusia, Graha Ilmu, Yogyakarta

Siagian, Sondang P. 2009. Kiat Meningkatkan Produktivitas Kerja. Jakarta: AsdiMahasatya.

Siagian. Sondang P. 2010. Manajemen Sumber Daya Manusia, Bumi Aksara, Jakarta

Suwatno.2011. Manajemen SDM dalam organisasi Publik dan Bisnis. Bandung: Alfabeta.

Tika, Pabundu. (2006). Budaya Organisasi dan Peningkatan Kinerja Perusahaan. Jakarta:Bumi Aksara.

Ujang Wawan Sam Adinata (Pengaruh Kepemimpinan Transformasional, Motivasi, Dan Budaya Organisasi Terhadap Kinerja Karyawan KJKS Bmt Tamzis Bandung Jurnal Ekonomi, Bisnis \& Entrepreneurship Vol. 9, No. 2, Oktober 2015, 136-157 ISSN 24432121

Umar, Husain. 2005.Manajemen Riset dan Perilaku Konsumen.Jakarta: PT Gramedia Pusat

Wibowo. (2010). Manajemen Kinerja.Jakarta: Rajawali Press.

Yukl, Gary, 2010, Kepemimpinan dalam Organisasi, Edisi Kelima. Jakarta: PT. Indeks. 